\title{
1. The evolution of unjust enrichment law: theory and practice
}

\author{
Elise Bant, Kit Barker and Simone Degeling ${ }^{l}$
}

In 1985, Peter Birks said in his characteristically incisive prose: '[i]t ought to be possible to take any legal subject and to cut away its detail so as to reveal the skeleton of principle which holds it together'. ${ }^{2}$ He lamented that the common law of restitution lacked any agreed framework and stood in danger of being unintelligible.

Some 30 years on - a mere blink in the eye of the law's development - that position has changed, in no small part due to the efforts of leading scholars such as Birks. ${ }^{3}$ This collection draws on that work, and the case law that has developed in conversation with it, to provide a rigorous overview of the major concepts and debates that inform the laws of unjust enrichment and restitution. The handbook aims to serve as the ideal springboard for the scholar, practitioner, law reformer or judge seeking access to and understanding of this challenging, complex and critically important field of private law. To that end, it identifies and engages with the core features of claims, defences and remedies falling within the compass of the laws of unjust enrichment and restitution, drawing on leading authorities, statutes and scholarship. The approach is determinedly comparative, seeking to draw parallels and distinctions between the treatments of shared factual patterns experienced across common and civil law jurisdictions. The end result is a web of insights that we hope will stimulate judicial, academic and regulatory analysis, legal practice and development for many years to come.

Part I of the collection seeks to identify and position key unjust enrichment and restitution concepts in light of broader historical, jurisdictional and theoretical perspectives. It then turns in Part II to consider fundamental, taxonomical questions concerning the categorisation, order and structure of the law, both internally and by reference to its broader legal context. Part III lays the theoretical foundations of the doctrinal analysis developed in Part IV, together offering a detailed and subtle understanding of the principles and rules that form the heartland of the laws of unjust enrichment and restitution. Part V offers a taxonomy and examination of the key defences that operate to restrict or deny restitutionary liability. Part VI concludes with an

1 Our sincere thanks to Justice James Edelman for kindly agreeing to write the Foreword to this handbook. The profound influence of his work as scholar and judge resonates throughout the collection. We would all like to acknowledge the debt of gratitude we owe to our research assistants: Isabel Chong, Michael Dardis, Olivia Gould-Fensom, Sophie Ward and Anna Kretowicz, for their patient assistance in putting together this collection. Simone Degeling also expresses her thanks for the financial support for research at UNSW Law provided by the Automic Group.

2 P Birks, An Introduction to the Law of Restitution (Oxford, Oxford University Press, 1985) 1 ('Introduction').

3 On the development of the common law of unjust enrichment and restitution as a whole and the role of scholars in that work, see in particular Ibbetson (Chapter 2), Kull (Chapter 4), Scott (Chapter 8). See also A Goymour, 'Reflections on the Restitution Revolution: England' in S Worthington, A Robertson and G Virgo (eds), Revolution and Evolution in Private Law (Oxford, Hart Publishing, 2018) 193. 
examination of the distinctive forms of restitutionary remedies that may respond to events of unjust enrichment.

\section{HISTORY AND COMPARATIVE INSIGHTS}

The history of unjust enrichment law is long and rich in both civilian and common law traditions. In Chapter 2, David Ibbetson opens the collection with an exposition of the subject's 'Development at Common Law', beginning with the forms of action in the period following the mid-twelfth century and concluding in 1991 with the case that arguably founds its modern treatment in England and Wales, Lipkin Gorman v Karpnale. ${ }^{4}$ His analysis of the broad sweep of cases and scholarship over this extended period emphasises the slow, ungainly and (until modern times) largely untheorised development of the law. In its earliest phases, the forms of action rendered pointless (indeed, impossible) any efforts to determine the doctrinal or theoretical foundations on which claims were based. Contemporaneous scholarship borrowed wholesale from The Institutes of Justinian ${ }^{5}$ to introduce the language and intellectual impediments of quasi contract, which did not reflect English practice and instead operated to forestall any mapping of the underlying principles. Lord Mansfield's attempts in 1760 in Moses $v$ Macferlan ${ }^{6}$ to impose some theoretical unity on the subject and liberate the common law from the shackles of this 'implied contract' analysis failed to gain widespread acceptance, in part due to the ongoing influence of the forms of action. Meanwhile, Chancery developed its own gain-based remedies in the form of constructive and resulting trusts, but their rationale remained shrouded in uncertainty. Despite the occasional suggestions to this effect in more recent times, they were unlikely to have provided the foundations for Lord Mansfield's famous statement that the origins of restitution lie in 'the ties of natural justice' and 'equity'. ${ }^{7}$ It was not until the famous article by legal historian, James Barr Ames in the late nineteenth century, that English law saw articulated 'the fundamental principle of justice that no one ought unjustly to enrich himself at the expense of another'. ${ }^{8}$ Again influenced by Roman 1 law $^{9}-$ this time through the work of French theorist Savigny ${ }^{10}$ - Ames set in train a course of theoretical work by legal historians and, in time, by courts, which culminated in the seminal work of Robert Goff and Gareth Jones ${ }^{11}$ and Peter Birks, ${ }^{12}$ on which Lipkin Gorman v Karpnale was founded. The intellectual debt of the developed law of unjust enrichment to comparative law and to academic scholarship is striking and continues to be evident throughout this collection.

In Chapter 3, James Gordley builds on Ibbetson's work by providing the first of many comparative insights into the structure and history of the modern law offered by this collection, ${ }^{13}$

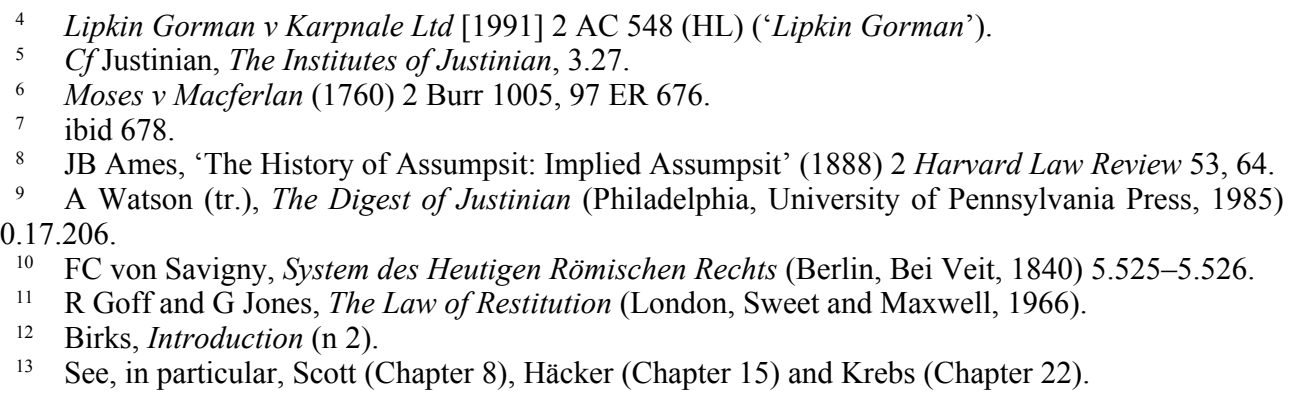


paying particular attention to the contributions of an important group of civil jurists known as the 'late scholastics' writing in the sixteenth and seventeenth centuries. Modern approaches to the analysis of unjust enrichment law, he recognises, fall into two main camps. The approach endorsed in most common law jurisdictions is one that looks for particular, positive reasons why a given enrichment obtained by the defendant is unjust ('unjust factors', such as the existence of mistake or duress), usually requiring the plaintiff to prove them as a first priority if restitution is to be obtained. ${ }^{14}$ The second, which is endorsed in many modern civilian and mixed jurisdictions, inquires whether the defendant's enrichment is justified by a relevant ground ('causa', such as a valid contract or gift), the absence of any ground for the enrichment providing courts' main focus and justifying relief. ${ }^{15}$ Whether the initial focus is on unjust factors, or the 'absence of grounds' for enrichment, however, both types of approach place the search for identified grounds (either for or against) restitution at the heart of the modern analysis of unjust enrichment law. In truth, all systems (more or less explicitly) take account of both reasons for and against restitution, the main differences between them consisting in the way in which they structure those reasons in formal legal analysis.

By contrast, Gordley suggests a third approach, which asks solely whether a defendant has been enriched 'at another's expense' by using the other's 'resources' (entitlements). This approach, he suggests, was pioneered by the late scholastics (though it has since been forgotten) and connects unjust enrichment law to its philosophical roots in corrective or commutative justice. ${ }^{16}$ On Gordley's approach, there is therefore no need for any additional analytical inquiry beyond those set out in Chapters 13 and 14 of this collection (has the defendant been enriched, was the enrichment at the plaintiff's expense?) and the material in Chapters 15 to 19, which details 'unjust factors' and 'legal grounds for enrichment', disappears from view. Although this might appear, at first glance, to make that material redundant, the single analytical question Gordley poses is itself richly normatively packed. In practice, we suggest, it is likely to require the same sort of investigation into specific reasons for (and against) restitution as the other, more familiar approaches. This is because the question of when a defendant has 'gained from the plaintiff's resources' is likely to require an inquiry into the extent of the plaintiff's initial 'entitlement' and into the precise circumstances which validate or invalidate its transfer to, or acquisition by, the defendant. The important point to be gleaned from this is that, while one can analyse the material of unjust enrichment law in several different ways, the material itself remains the same. The question is, which is the most useful analytical approach to adopt and what practical difference does it make if one takes one approach, not another?

See Chapters 16 to 19 for discussion of these factors.

See Chapters 8 and 15 for consideration of this type of approach.

16 For explanation of these ideas, see generally Part III. Gordley connects his views in particular to the work of Weinrib (Chapter 9) and Klimchuk (Chapter 10). For a fascinating account of the historical development of the idea of corrective justice, see I Englard, Corrective and Distributive Justice from Aristotle to Modern Times (Oxford, Oxford University Press, 2009). 


\section{TAXONOMY}

Taxonomy is a purely organisational exercise, but the way one organises legal material has significant legal implications. ${ }^{17}$ Part II of the collection turns from legal history to modern debates about where the subject law fits on the modern private law 'map' and how it intersects with the other recognised private law 'categories' such as contract, tort, equity and property. Not all of these other categories are organised around common, substantive principles - for example, the category of 'equity' is drawn up along historical, jurisdictional, not substantive lines, so that the two categories can intersect without contradiction. ${ }^{18}$ Unjust enrichment claims can hence be equitable, just as buildings can be both Georgian and blue. Some common law jurisdictions - Australia in particular - continue to struggle with this truth and still occasionally see the categories as being normatively opposed. ${ }^{19}$ Civilian systems do not have a jurisdictional category of 'equity' and are blissfully free of this complication. ${ }^{20}$ On one view, there is no contradiction between unjust enrichment and property either, since property is a consequence of legal events, not a legal event in itself. ${ }^{21}$ This means that unjust enrichment can sometimes give rise to a right in the plaintiff to claim specific property that the defendant has obtained at his expense. ${ }^{22}$ More contested are cases in which the plaintiff is

17 E McKendrick, 'Taxonomy: Does it Matter?' in D Johnston and R Zimmermann (eds), Unjustified Enrichment: Key Issues in Comparative Perspective (Cambridge, Cambridge University Press, 2002) 627. Cf S Hedley, 'Rival Taxonomies within Obligations: Is There a Problem?' in S Degeling and J Edelman (eds), Equity in Commercial Law (Sydney, Lawbook Co, 2005) 77.

18 P Birks, 'Equity in the Common Law: An Exercise in Taxonomy' (1996) 26 University of Western Australian Law Review 1, 67 ('Equity in the Common Law').

19 For a particularly jarring example, in which the frameworks were seen by some members of the High Court to be diametrically opposed, see Farah Constructions v Say-Dee Pty Ltd [2007] HCA 22, (2007) 230 CLR 89 ('Farah'). In more recent years, attitudes appear to be changing - the Court reiterating that, far from being in conflict, 'legal principles of restitution or unjust enrichment can be equated with seminal equitable notions of good conscience': Equuscorp Pty Ltd v Haxton [2012] HCA 7, (2012) 246 CLR 498 [32] (French CJ, Crennan and Kiefel JJ). See generally Ho (Chapter 7).

20 Similarly, in the United States, the debate about 'equity' is not a jurisdictional one, but one about whether we need secondary principles to moderate the bluntness of first order rules: H Smith, 'Fusing the Equitable Function in Private Law' in K Barker, K Fairweather and R Grantham (eds), Private Law in the 21st Century (Oxford, Hart Publishing, 2017) 173.

${ }_{21}$ Birks, 'Equity in the Common Law' (n 18) 81; P Birks, 'Property and Unjust Enrichment: Categorical Truths' [1997] New Zealand Law Review 623; P Birks, Unjust Enrichment, 2nd edn (Oxford, Oxford University Press, 2005) 36. For the view that 'property' itself constitutes an event to which remedies (including restitutionary remedies) respond, see W Swadling, 'Property and Unjust Enrichment' in JW Harris (ed.), Property Problems: From Genes to Pension Funds (London, Kluwer, 1997) 130; R Grantham and C Rickett, 'Property Rights as a Legally Significant Event' (2003) 62 CLJ 717; G Virgo, The Principles of the Law of Restitution, 3rd edn (Oxford, Oxford University Press, 2015) 557-65; Foskett v McKeown [2001] 1 AC 102 (HL) ('Foskett'). The idea that property is a category of law in its own right is so firmly entrenched that it is unlikely easily to be displaced.

22 See generally Liau and Leow (Chapter 24). The literature addressing the circumstances in which P may have a proprietary, as opposed to a personal claim is vast. See, for starters: D Hayton, 'Constructive Trusts: Is the Remedying of Unjust Enrichment a Satisfactory Approach?' in T Youdan (ed.), Equity, Fiduciaries and Trusts (Zurich, Carswell, 1989) ch 9; R Goode, 'Property and Unjust Enrichment' in A Burrows (ed.), Essays on the Law of Restitution (Oxford, Clarendon Press, 1991) 215; 'Proprietary Restitutionary Claims' in WR Cornish, R Nolan, J O'Sullivan and G Virgo (eds), Restitution, Past Present and Future (Oxford, Hart Publishing, 1998) ch 5; P Birks, 'Property in the Profits of Wrongdoing' (1994) 24 University of Western Australia Law Review 8; Birks, Unjust Enrichment (n 
claiming from the defendant property (or the value of property) to which she has retained title throughout; ${ }^{23}$ or property (or the value of property) which is the traceable product of property that the plaintiff once owned..$^{24}$ In the former case, it is often suggested that the claim to the property's value is an unjust enrichment claim, even if the claim to the property itself is based on the plaintiff's persisting ownership of it..$^{25}$ In the latter case, by contrast, some courts and commentators have suggested that restitutionary claims to the value of the property are based on the plaintiff's original title to it, not on unjust enrichment, even though the claim is a personal one and intermixtures or substitutions have caused the original title to be lost. ${ }^{26}$ These debates are technical, complex and canvassed at later stages of the collection. A key priority in working them out is to ensure that the application of the logic of unjust enrichment law to cases in which the defendant's benefit consists in the receipt of property does not contradict existing, well-grounded principles of property law. Indeed, the need to retain 'coherence' between the law's different categories and aims is a consistent, modern refrain. ${ }^{27}$

The proper relationship between different legal categories is one aspect of the debate about coherence. Another relates to the internal order of the category of unjust enrichment law itself. Does the category comprise all the (diverse) cases in which restitution and disgorgement of gains are available, or only a smaller, tighter group? In Chapter 4, Kull leads us into this debate with an account of the early origins and later development of the category of unjust enrichment law in the United States - the first common law jurisdiction to give the subject independent taxonomic space. As he recounts, the first formal statement of the subject in that jurisdiction in 1932 - for reasons as much to do with the preference of its publishers for brevity as any other reason - bore the title 'restitution', not 'unjust enrichment.' This was a mistake from the

21) ch 8; W Swadling, 'Policy Arguments for Proprietary Restitution' (2008) 28 Legal Studies 506; B Häcker, 'Proprietary Restitution after Impaired Consent Transfers: A Generalised Power Model' (2009) 68 CLJ 324; A Burrows, The Law of Restitution, 3rd edn (Oxford, Oxford University Press, 2011) ('Restitution') ch 8; A Burrows, A Restatement of the English Law of Unjust Enrichment (Oxford, Oxford University Press, 2012) $\S \S 35,159-71$ ('Restatement'); E Bant and M Bryan, 'Constructive Trusts and Equitable Proprietary Relief: Rethinking the Essentials' (2011) 5 Journal of Equity 171; 'A Model of Proprietary Remedies' in E Bant and M Bryan (eds), Principles of Proprietary Remedies (Sydney, Lawbook Co, 2013) 215; E Bant, 'Constructive Trusts, Unconscionability and the Necessity for Working Criteria' (2014) 8 Journal of Equity 259; J Edelman, 'Restitution of Property Rights' in E Bant and M Bryan, Principles of Proprietary Remedies (Sydney, Lawbook Co, 2013) ch 3; Virgo, The Principles of the Law of Restitution (n 21) pt IV, esp ch 21; C Mitchell, P Mitchell and S Watterson, Goff \& Jones: The Law of Unjust Enrichment, 9th edn (London, Sweet and Maxwell, 2016) chs 37-40 ('Goff \& Jones').

${ }_{23}$ Where the claim is in respect of personal property, such claims - whether resulting in an award of the property's value, or return of the property itself - tend, in common law jurisdictions, to be conceptualised as based on the wrong of interfering with P's title (trespass, detinue, conversion, or 'knowing receipt' of trust property), not unjust enrichment, or even 'property'. But academic views differ (see the text below) and civilian jurisdictions have an action (the vindicatio) which directly vindicates P's property right.

24 Lipkin Gorman (n 4); Foskett (n 21).

25 See further McInnes (Chapter 13) and Bryan (Chapter 18).

26 Virgo, The Principles of the Law of Restitution (n 21) 560-5; Foskett (n 21). Contrast J Edelman and E Bant, Unjust Enrichment, 2nd edn (Oxford, Hart Publishing, 2016) 102-3; Trustee of the Property of FC Jones \& Sons v Jones [1997] Ch 159 (CA).

${ }_{27}$ On the meaning of the idea of coherence, see A Fell, 'The Concept of Coherence in Australian Private Law' (2018) 41 Melbourne University Law Review 1160. 
taxonomic point of view, ${ }^{28}$ because all of the other categories of private law with which we are familiar (contract, for example) identify particular types of event (causes of action) giving rise to legal claims, not particular sorts of remedy, and restitution is a remedy, not a cause of action. Both terms now appear in the title of the most recent Restatement ${ }^{29}$ and a significant number ${ }^{30}$ of modern books and courts now consider unjust enrichment the proper category of reference.

Although the titular question may now have been largely settled, debate nonetheless persists about the proper scope of the new category of unjust enrichment law. In the United States (and Germany), it includes enrichments obtained by a civil wrong, ${ }^{31}$ whereas in England (and possibly Australia) courts increasingly take the view that restitution (and disgorgement) for wrongs belong in the separate category of 'wrongs' (tort, contract, breach of fiduciary duty and so on), not 'unjust enrichment', ${ }^{32}$ thereby making the latter category smaller. Some writers espouse a narrower view of the subject still, reducing it to cases that are most closely analogous to cases of mistaken payment. ${ }^{33}$ This would exclude not just the material considered by Craig Rotherham in Chapter 5, but at least some of the examples considered by Charles Mitchell in Chapter 19, where restitution is ordered for 'other' reasons. Kull prefers the American 'big tent' view. On this approach, unjust enrichment is akin to the law of torts in the sense that it is a conglomeration of different causes of action, with only limited, stable features in common. ${ }^{34}$ By contrast, narrower approaches purport to make the law of unjust enrichment more unified or 'coherent' and in this regard (only) more akin to the law of contract. In deliberately shrinking the category, they leave a considerable number of cases involving restitution and disgorgement scattered across other legal domains, some of which cases are so isolated and unconnected to one another that the causes of action that ground them have to be grouped under the heading

28 Although he notes that it did not cause any real misunderstanding amongst the legal community at the time.

29 Restatement of the Law Third: Restitution and Unjust Enrichment (St Paul, American Law Institute, 2011) ('Restatement').

30 See, e.g., Birks, Unjust Enrichment (n 21); Goff \& Jones (n 22); Edelman and Bant (n 26). There are exceptions, e.g., Virgo, The Principles of the Law of Restitution (n 21); Burrows, Restitution (n 22); I Jackman, The Varieties of Restitution, 2nd edn (Sydney, Federation Press, 2017); K Mason, JW Carter and GJ Tolhurst, Mason and Carter's Restitution Law in Australia, 3rd edn (Sydney, LexisNexis Butterworths, 2016).

31 Restatement (n 29) comment (a) to s 1.

32 Sempra Metals Ltd v Inland Revenue Commissioners [2007] UKHL 34, [2008] AC 561 [116] (Lord Nicholls); [230]-[231] (Lord Mance); Benedetti v Sawiris [2013] UKSC 50, [2014] AC 398 [24] (Lord Clarke); Investment Trust Companies v Revenue and Customs Commissioners [2017] UKSC 29, [2018] AC 275 [42] (Lord Reed, Lords Neuberger, Mance, Carnwath and Hodge agreeing) ('Investment Trust') (the purpose of unjust enrichment is to correct 'normatively defective transfers of value'); Swynson v Lowick Rose LLP (in liq) [2017] UKSC 32, [2018] AC 313 [22] (Lord Sumption, Lords Neuberger, Clarke and Hodge agreeing) ('Swynson'); Farah (n 19) [150] (suggesting that cases of breach of fiduciary duty 'have been said to be foreign to unjust enrichment notions').

33 Birks, Unjust Enrichment (n 21) 3, 16. For a review of the various different positions taken on the subject's scope, from the point of view of a sceptic, see S Hedley, 'Unjust Enrichment: A Middle Course?' (2002) 2 Oxford University Comparative Law Journal 181.

34 See, similarly, K Barker, 'Understanding the Unjust Enrichment Principle in Private Law: A Study of the Concept and its Reasons' in JW Neyers, M McInnes and SGA Pitel (eds), Understanding Unjust Enrichment (Oxford, Hart Publishing, 2004) 79; K Barker, 'Unjust Enrichment in Australia - What Is(n't) it? Implications for Legal Reasoning and Practice' (2020) 43 Melbourne University Law Review (forthcoming). 
of 'miscellaneous other'. ${ }^{35}$ In order to accommodate the wide range of views about the proper scope of the subject, we have purposely titled this work 'Unjust Enrichment and Restitution', thereby leaving it to readers to determine for themselves which cases of restitution belong within the category of unjust enrichment law and which (if any) fall outside it. An irony but perhaps also a reassurance - is that those who fiercely endorse rival 'broad' or 'narrow' positions concerning the subject's scope often agree about the substantive content of the legal rules which it contains. The question is whether the prerogative that the category be highly coherent is sufficiently compelling to justify restricting its ambit, or whether a looser, more diverse category with greater internal variation has additional interpretive advantages. As with all matters of categorisation, this is likely to depend largely on the purposes of the interpreter.

In Chapter 5, Craig Rotherham takes us further into the heartland of the above debate about restitution for wrongs. The common law, he explains, draws an important distinction between cases of enrichment by wrongdoing and cases of enrichment 'by subtraction'. In cases of enrichment by subtraction, the defendant's benefit is derived from the plaintiff's wealth and restitution is available simply on proof that there was a defect in the transfer between the two. By contrast, in cases of enrichment by wrongdoing, the defendant's benefit is obtained by infringing one of the plaintiff's rights (often, but by no means always, a property right) and the gain need not correspond to any loss on the plaintiff's part. Rotherham's central argument is that, while some accounts of restitution for wrongs suggest that such claims will generally be accompanied by a parallel claim for unjust enrichment 'by subtraction' on the basis that the defendant's wrong simultaneously subtracts a plaintiff's 'right', ${ }^{36}$ wrongs do not necessarily result in anything being transferred to the defendant. This is because a wrongdoer does not obtain a plaintiff's rights by breaching them - indeed, it is precisely because the plaintiff's rights remain intact that he or she can sue when they are breached. ${ }^{37}$ For this reason, cases of enrichment by wrongdoing must stand analytically apart from cases involving subtraction.

Another thorny taxonomic issue within this field considered by Rotherham relates to the proper analysis of cases in which plaintiffs are awarded a 'reasonable fee' for the infringement of their rights in the form of 'release fees' or 'hypothetical bargain' damages. ${ }^{38}$ The current judicial orthodoxy is that such awards compensate the plaintiff for a loss and that they therefore lie outside the category of unjust enrichment and restitution altogether. Rotherham argues that such analyses are unsatisfactory, being inconsistent with the tendency of courts to take a gain-based approach to quantification and their readiness in some cases to grant defences to blameless wrongdoers. He also considers an associated, difficult, substantive question, namely whether (and if so when) gain-based relief for wrongdoing should be limited to a release fee, or extend, through an account of profits, to all gains causally linked to the wrong. Unlike release fees, such awards are indisputably gain-based, but the principles governing their availability are currently unclear. He astutely suggests that this uncertainty is bound to persist, as long as

\footnotetext{
35 Birks, Unjust Enrichment (n 21) 24-8.

36 J Beatson, 'The Nature of Waiver of Tort' in J Beatson, Use and Abuse of Unjust Enrichment (Oxford, Clarendon Press, 1991) 232. See also J Edelman who similarly argues that reasonable fee awards function to reverse the transfer of a benefit from the plaintiff to the defendant: J Edelman, Gain-based Damages: Contract, Tort, Equity and Intellectual Property (Oxford, Hart Publishing, 2002)

37 C Rotherham, 'The Conceptual Structure of Restitution for Wrong' (2007) 66 CLJ 172.

38 See also Barnett (Chapter 23).
} 7. 
courts continue to rely upon the question-begging criterion of 'exceptional circumstances'. ${ }^{39}$ We need clearer rules and principles to distinguish an 'exceptional' case.

In Chapter 6, Tang Hang Wu turns to the relationship between unjust enrichment and contract. He first considers the now discredited 'implied contract' theory of restitutionary obligation, referred to above in our discussion of Ibbetson's historical work in Chapter 2. This consisted in courts fictionally imputing a contract between the plaintiff and the restitutionary defendant, according to which the defendant agreed to repay the plaintiff. That fiction was responsible, for many years, for the law of restitution being appended at the back of contract books, when restitutionary obligations are in reality imposed by courts, not agreed by the parties. He also draws attention to the principle that a claim for unjust enrichment law may usually only operate if there is no valid contract between the plaintiff and the defendant. This is arguably to prevent the subversion of the parties' agreed distribution of risk. That logic means, however, that restitution might theoretically be available even in cases involving valid contracts, provided that the agreed contractual risk allocation is not undermined. This is consistent, he suggests, with the leading decision of the High Court of Australia in Roxborough $v$ Rothmans of Pall Mall Australia Ltd ${ }^{40}$ and with courts' assertion that restitution is precluded if the terms of a contract between the parties expressly or impliedly excludes an unjust enrichment claim. He then considers the implication of this approach in surveying a number of distinct categories of case in which restitution is sought following the breach of a contract, when the contract is void, or when it has failed to materialise as expected.

A final, difficult, aspect of the relationship between contract and unjust enrichment which Tang considers is the extent to which a court should take into account the terms of any failed contract in valuing the defendant's enrichment in a restitutionary claim. The situation is illustrated by the well-known case of Boomer $v$ Muir. ${ }^{41}$ Boomer (the innocent party) had already been paid in stages for works it had carried out. Only a further $\$ 20,000$ remained to be paid under the contract. When Storrie \& Co breached, Boomer elected to terminate the contract and claimed remuneration for the work done at the market rate. Dooling J held that Boomer was indeed entitled to terminate and awarded him an additional $\$ 258,000$. As Tang points out, the same conceptual point arose recently in the High Court of Australia in Mann v Paterson Constructions Pty Ltd. ${ }^{42}$ The plurality of Nettle, Gordon and Edelman JJ stated that in cases involving the termination of a valid contract for breach, the valuation should prima facie not exceed the contract price, ${ }^{43}$ but did not rule out the possibility of it doing so in an exceptional

\footnotetext{
Rotherham (Chapter 5).

Roxborough v Rothmans of Pall Mall Australia Ltd [2001] HCA 68, (2001) 208 CLR 516.

Boomer v Muir 24 P2d 570 (Cal Ct App 1933).

Mann v Paterson Constructions Pty Ltd [2019] HCA 32, (2019) 93 ALJR 1164 ('Mann').

43 ibid [205]. Their Honours later qualify this statement at [215] so as to limit the reach of Mann to

a contract, although discharged, should inform the content of the defendant's obligation ... to make restitution where the failed basis upon which the work and labour was performed was the contractor's right to complete the performance and earn the price according to the terms of the contract. It is, therefore, appropriate to recognise that, where an entire obligation (or entire divisible stage of a contract) for work and labour (such as, for example, an entire obligation under or an obligation under a divisible stage of a domestic building contract) is terminated by the plaintiff upon the plaintiff's acceptance of the defendant's repudiation of the contract, the amount of restitution recoverable as upon a quantum meruit by the plaintiff for work performed as part of the entire obligation (or as part of the entire divisible stage of the contract).
} the following case: 
case, if it would be unconscionable to confine the plaintiff to the contractual measure on account of the way the defendant had behaved. Boomer was cited as a possible example of such an exceptional case. ${ }^{44}$ Gageler $\mathbf{J}$ was more emphatic, stating that the valuation 'cannot exceed that portion of the contract price as is attributable to those services'. ${ }^{45}$

In Chapter 7, Lusina Ho addresses the complex relationship between unjust enrichment and equity. In doing so, she examines their theoretical relationship to one another as categories, the role of ideas of conscience, unconscionability and 'unconscientious retention' as the drivers of claims within unjust enrichment law and a number of sites of conflict and tension between rules developed at common law and in equity in cases involving mistake, the receipt of misdirected assets and tracing rules. In seeking to bring coherence and better understanding to the relationship between equity and unjust enrichment in the era after Australian Financial Services and Leasing Pty Ltd v Hills Industries Ltd ${ }^{46}$ she highlights key questions about the proper role of fault within the modern law, and points to the danger of assimilating all claims falling within the unjust enrichment category in ways that potentially blind one to differences in their underlying logic and the context in which they were developed. In particular, she considers the equitable doctrines of undue influence, knowing receipt, mistaken gifts and tracing and the extent to which 'unjust enrichment' provides a useful taxonomical label or unifying legal principle in these examples. The tenor of her chapter leads one to suspect that, despite what we have suggested above about the non-opposition of equity and unjust enrichment as categories, the conflict continues to play out in the cases at a lower level when it comes to determining how to formulate particular legal rules.

This part of the book concludes in Chapter 8 with a detailed, comparative examination of the way in which civilian and mixed jurisdictional systems have come to organise unjust ('unjustified') enrichment law and a helpful assessment of the extent to which civilian ideas have been received in common law systems and legal scholarship. Drawing extensively on the rich legal history and academic traditions of civilian systems, Helen Scott provides a wonderfully clear depiction of the complex taxonomy of unjust enrichment law in France, Germany, Scotland, South Africa and common law Canada, in each case detailing the way in which the current organisation has come about. Close attention to her work demonstrates that, although the basic rules governing restitutionary recovery are often similar to those extant in common law systems (and often similar to those in other civilian jurisdictions too), they are organised in subtly different ways. Each system has struggled in its own circumstances to articulate the relationship between the higher-level organising principle and particular cases, actions and rules; and with the need to accommodate, whether overtly or covertly, both specific reasons for restitution and bases upon which the retention of an enrichment may be justified.

Drawing upon this material, Scott argues that civilian systems have recently been influential on the common law tradition in at least two, crucial ways - firstly, in persuading Peter Birks to abandon the traditional 'unjust factors' approach in favour of the 'absence of basis' approach;

\footnotetext{
Note also that the plurality stated that things will be different if the contract does not state a price at all, or if it was invalid from the start. In the former case, there is no limit at all and in the latter, the contract price merely provides inconclusive evidence of the value of the work for the purposes of the restitutionary claim: [203]-[204].

44 ibid [216].

45 Mann (n 42) [102].

46 Australian Financial Services and Leasing Pty Ltd v Hills Industries Limited [2014] HCA 14, (2014) 253 CLR 560 ('Hills Industries').
} 
and secondly, in yielding a new wave of scepticism amongst common law writers about the extent to which it is possible to have a general unjust enrichment principle at all. As regards the first of these developments, she suggests that it is unlikely that approaches based 'purely' on unjust factors, or 'absence of a basis' will ultimately prove satisfactory and takes the view, to which we have alluded above, that mixed approaches combining the analysis of both unjust factors and grounds for a defendant's enrichment are most likely to capture the complexity of restitutionary causes of action. As regards the second issue, she points out that, although civilian systems are often thought to be more strongly wedded to the recognition of general, abstract principles, recent trends in Germany have been in the opposite direction, so that it is now commonly thought important to recognise significant diversity within the field, or even a more extreme view posited recently by Nils Jansen ${ }^{47}$ - to break the field of unjust enrichment law up completely. Each of these positions reverberates with the views of some recent writers in the common law tradition, who suggest either that we should recognise a more pluralist, less 'unified' unjust enrichment law, or that we should abandon the category entirely. Although she wisely does not prophesy the future, she hints that the pluralists are more likely to hold the day than those who would abandon the category of unjust enrichment law altogether; and points, in any event, to the value of the engagement on such issues between lawyers steeped in the common law and civilian traditions.

\section{PHILOSOPHICAL FOUNDATIONS}

Literature exploring in concerted fashion the philosophical foundations of unjust enrichment law is a recent phenomenon. The reason is easy to grasp - there was little basis for interrogating the normative underpinnings of the subject until such time as its existence was confidently affirmed. The deficit was noted in England in the mid-1990s and first steps taken to remedy it. ${ }^{48}$ Since that time, there has been an explosion of interest. ${ }^{49}$ Here, the theories divide between the view that restitution serves (or should serve) forward-looking, instrumental ends (such as economic efficiency ${ }^{50}$ or the deterrence of wrongdoing) on the one hand, or backward-looking moral/deontological aims, on the other, such as the desire to do corrective ${ }^{51}$ or distributive justice, ${ }^{52}$ or (perhaps, more contentiously, since private law does not normally impose moral duties) to ensure that the defendant acts virtuously. ${ }^{53}$ In part, perhaps, because the case in which the defendant receives a mistaken payment has been regarded from the beginning as the 'core' example of unjust enrichment, many philosophical contributions have focused on trying to explain why the defendant must make restitution in this particular case. This has proven more difficult than one might imagine. A key difficulty resides in the fact that a mistake in

\footnotetext{
47 N Jansen, 'Farewell to Unjustified Enrichment?' (2016) 20 Edinburgh Law Review 123.

48 K Barker, 'Unjust Enrichment: Containing the Beast' (1995) 15 Oxford Journal of Legal Studies 457, 463-74.

49 For references to the literature, see Chapters 9-12.

50 See Wonnell (Chapter 11).

51 See Weinrib (Chapter 9); Klimchuk (Chapter 10).

52 See Dagan (Chapter 12) and, more generally, H Dagan, The Law and Ethics of Restitution (Cambridge, Cambridge University Press, 2004).

53 JE Penner, "We All Make Mistakes: A "Duty of Virtue" Theory of Restitutionary Liability for Mistaken Payments’ (2018) 81 MLR 222.
} 
making a payment does not stop the defendant becoming owner of the money. The same is true in a great number of (some say all) unjust enrichment cases. Why, then, is the defendant obliged to give it (or its value) back to the plaintiff? ${ }^{54}$

In Chapter 9, Ernest Weinrib articulates the view, for which there is some judicial authority, ${ }^{55}$ that restitution for unjust enrichment (understood as cases like the mistaken payment case) follows the moral logic of corrective justice - setting right the moral imbalance between the doer and sufferer of an interpersonal injustice and restoring them to their rightful pre-transactional positions. Drawing on both Aristotle (for the form of corrective justice) and Kant (for its substantive content) Weinrib makes a sophisticated claim that corrective justice explains restitution even in cases, like the mistake case, in which the defendant has done nothing to bring about the plaintiff's payment. The injustice calling for correction in this instance lies, he argues, in the combination at once of the failure of the plaintiff's will in making the payment (the mistake) and the instantiation of the defendant's own will in accepting it. Since it is wrong (on the Kantian view) to subject another's will to one's own purposes, the defendant must make restitution of the value of the payment to the plaintiff. A strength of Weinrib's approach is that it neatly fits the bipartite structure of unjust enrichment litigation - it explains coherently why the plaintiff is entitled to claim money from the defendant (and no one else) and why the defendant (and no one else) is obliged to pay the plaintiff. That is harder to explain if the only purpose in making the defendant pay is an instrumental one, such as the desire to make sure that she is more careful in the future about checking her receipts. Rather trickier for Weinrib is the question whether the sort of 'acceptance' that he says triggers restitution in the mistaken payment case, which can be instantiated simply by the defendant receiving something that objectively meets her purposes, is really sufficient to make her a purposive agent of the plaintiff's loss in a sense sufficient to require her personally to correct it.

In Chapter 10, Dennis Klimchuk expresses some doubt about this aspect of the Weinrib account and explores a number of other possible explanations for restitution in the same, 'core' case of mistake. One of these is a second type of 'corrective justice' argument based on the idea that the defendant must make restitution because, even though he is now the legal owner of the money, the 'moral' title to it still belongs to the plaintiff (we may observe the connection here to Gordley's view, above, that the defendant benefits in such a case from the plaintiff's 'entitlements'). This is just one variant of a number of 'property theories' dating back as far as Aquinas but more recently reinvigorated in the literature, ${ }^{56}$ which might explain why the

\footnotetext{
54 F Wilmot-Smith, 'Should the Payee Pay?' (2017) 37 Oxford Journal of Legal Studies 844. This question is a particular focus for Klimchuk (Chapter 10).

${ }_{55}$ Peel (Regional Municipality) v Canada [1992] 3 SCR 762, 804 (McLachlin J); Kingstreet Investments $v$ New Brunswick (Department of Finance) [2007] 1 SCR 3 [32]; Benedetti v Sawiris [2013] UKSC 50, [2014] AC 938 [97] (Lord Reed); Investment Trust (n 32) [42]-[43] (Lord Reed, Lords Neuberger, Mance, Carnwath and Hodge agreeing); Swynson (n 32) [22] (Lord Sumption, Lords Neuberger, Clarke and Hodge agreeing).

${ }_{56}$ See, e.g., SJ Stoljar, The Law of Quasi Contract (Sydney, Lawbook Co, 1964); P Jaffey, The Nature and Scope of Restitution (Oxford, Hart Publishing, 2000); P Jaffey, Private Law and Property Claims (Oxford, Hart Publishing, 2007); P Jaffey, 'Classification and Unjust Enrichment' (2004) 67 MLR 1012; A Botterell, 'Property, Corrective Justice and the Nature of the Cause of Action in Unjust Enrichment' (2007) 20 Canadian Journal of Law and Jurisprudence 275; JM Nadler, 'What Right does Unjust Enrichment Protect?' (2008) 28 Oxford Journal of Legal Studies 245; B McFarlane, 'Unjust Enrichment, Rights and Value' in D Nolan and A Robertson (eds), Rights and Private Law (Oxford, Hart Publishing, 2011) ch 21. The most significant, recent version of theory is to be found in C Webb,
} 
defendant has a direct responsibility to pay back the money to the plaintiff. He also considers a different possibility, which he himself at one time posited, ${ }^{57}$ which is that it is not corrective, but rather a form of localised distributive justice that requires restitution from the defendant. If the defendant is not a 'doer' of any injustice such that corrective justice requires repayment, then perhaps, he suggests, restitution is required just because this is the fairest way of distributing the plaintiff's loss between the plaintiff and the defendant, given the defendant's surplus and the plaintiff's unfortunate mistake. The key point about any distributive justice analysis is that the money in the defendant's possession can be allocated between the plaintiff and the defendant in accordance with a criterion (fairness, autonomy, or indeed anything else) that has nothing to do with whether or not the defendant did an injustice to the plaintiff in receiving it. And the benefit of the 'localised' form of the distributive justice argument in this instance, in contrast to other types of distributive justice argument that focus on creating fairness between broader groups, is that it can still explain the bipartite form of litigation. It can explain why only the defendant is an eligible candidate to pay the plaintiff, not, for example, some wealthy passer-by. All in all, Klimchuk provides an excellent, critical account of the wide range of non-instrumental arguments that can be made for restitution - corrective justice, distributive justice, 'equity', a duty on the part of the defendant to be virtuous, or (Dagan's view, below) 'relational justice', although he is keener on some of these possibilities than others and remains sanguine as to whether any of them holds the solution to all cases. A possible oversight of the account (and indeed perhaps also of Weinrib's) is in assuming that all unjust enrichment cases follow exactly the same normative pattern as the (supposedly) 'core' case of the spontaneous mistake. In many instances (for example, where the defendant has engaged in misrepresentation, undue influence, duress, or the receipt of benefits under a failed contract) the defendant will have done something to bring about the plaintiff's transfer and in any such case, corrective justice seems to be able to explain recovery with little difficulty, even taking account of the fact that liability is usually strict. ${ }^{58}$

In Chapter 11, Chris Wonnell provides an instrumentalist, economic perspective on restitutionary rules. He is careful to point out that, although economics is a forward-looking science concerned with the creation of incentives, those who use it are not necessarily committed to a utilitarian framework in which individual entitlements can be overridden just because this produces the greatest overall social good. Some economists (Wonnell included) take a more liberal normative position than this and see the science as a mechanism which, by promoting rational individual choices, can also bring social benefits insofar as it can maximise the means at people's disposal for pursuing their own ends. Through the course of the chapter, he illustrates how five different types of restitution case - cases of mistake, restitution for wrongs, the provision of benefits under failed contracts, gains made through breach of a contract and restitution of unsolicited benefits - can usefully be critiqued from this economic point of view.

Reason and Restitution (Oxford, Oxford University Press, 2016). For extensive critical analysis, see F Wilmot-Smith, 'Reasons? For Restitution?' (2016) 79 MLR 1116.

${ }_{57}$ D Klimchuk, 'Unjust Enrichment and Corrective Justice' in JW Neyers, M McInnes and SGA Pitel (eds), Understanding Unjust Enrichment (Oxford, Hart Publishing, 2004) 111.

${ }_{58}$ See K Barker, 'The Nature of Responsibility for Gain: Gain, Harm and Keeping the Lid on Pandora's Box' in R Chambers, C Mitchell and J Penner (eds), Philosophical Foundations of the Law of Unjust Enrichment (Oxford, Oxford University Press, 2009) 146, 178. Strict Liability is not an idea that is necessarily foreign to corrective justice theory. See, e.g., RA Epstein, 'Causation and Corrective Justice' (1979) 8 Journal of Legal Studies 477. 
By contrast with Weinrib's explanation, the economic explanation given for restitution in the mistake case is that if it were not made, there would be an incentive for the payer wastefully to expend too much in avoiding mistakes that have no cost to anyone other than himself. It is notable that some of the features of the law that are recommended by the economic analysis - for example that the plaintiff's own carelessness in paying should not preclude recovery are equally supported from Weinrib's corrective justice point of view, although the analyses diverge significantly in other cases. This sort of economic approach to the analysis of restitutionary rules is not common amongst judges, so it is perhaps better viewed as an external, normative critique than an internal explanatory account of the cases. As Wonnell's analysis demonstrates, in this role it is of great value.

In Chapter 12, Hanoch Dagan finishes this part of the book with a different view again. Broadly speaking, Dagan is a pluralist in the sense that he understands the law of restitution to reflect a variety of different social values in different contexts, not any, single one. In this chapter, he sets out what might be regarded as a broad form of distributive justice argument, ${ }^{59}$ namely that restitutionary rules aim (or should aim) to promote the autonomy of individuals in a positive, perfectionist liberal sense that makes them fully self-determining agents. This commitment to autonomy is markedly different to Weinrib's idea that the law is concerned only to correct interferences with individuals' purposes, requiring the endorsement of substantive, not merely formal, equality and demanding account be taken of human difference and interdependence. Applying this model to the mistaken payment case, restitution is justified because, although the defendant did nothing wrong in receiving the payment (and did not therefore interfere with the plaintiff's entitlements), he is under a duty to assist the plaintiff by returning the money, in order to respect and promote the plaintiff's autonomous choices about what to do with it (and therefore his life). The defendant's own autonomy is also protected by granting him a defence of change of position if he has made choices of his own in the meantime. Further, and consistently with the view that it is substantive equality that counts in matters of freedom, Dagan suggests that the rules governing restitution of mistaken payments should reflect differences in the power and informational sophistication of the parties, so that restitution should be more easily available to individuals from banks than vice versa. This analysis of the law as perfecting a form of 'relational justice' is further extended to cases in which the plaintiff benefits the defendant by advancing a joint project, cases of cohabitation and cases involving fiduciaries and intimates. Key components of the theory are that it is a legitimate part of the law of restitution's function to further welfarist public values and that one of these values is freedom - understood not simply negatively (protection against interferences with one's purposes, or what is one's own), but positively - comprising access to what one needs to be a fully autonomous, self-determining person.

Theories of unjust enrichment law can thus be divided not simply according to whether they are instrumentalist or non-instrumentalist, but also according to whether they see the law as pursuing one aim or many; and whether they are purely normative theories, or credibly claim to explain judges' actual reasoning in the cases. Which theory is thought best to explain the law will also be affected by how much taxonomic scope the subject is given. For example, those who think that cases of restitution for wrongdoing are part of unjust enrichment law are more likely to conclude that deterrence plays some role in the subject's rules, whereas those

59 Although Klimchuk does not list it as such. 
who think wrongs are excluded may be more attracted to non-instrumental views. There is therefore an important link between this part of the collection and the preceding one. In the same way, as the next part illustrates, there is an important interplay between the way in which the subject's normative underpinnings are understood and its core, structural features.

\section{ANALYTICAL STRUCTURE}

In common law systems, four key questions underpin the 'skeleton of principle' ${ }^{90}$ on which the laws of unjust enrichment and restitution are based: (1) was the defendant enriched; (2) at the expense of the plaintiff; (3) in circumstances where there is a recognised reason (an 'unjust factor') why the defendant should not be permitted to retain the benefit; and (4) is there a defence? A fifth question is the form of restitutionary order that may be made in response to a claim of unjust enrichment (the type of remedy available). Although this framework initially suggested that unjust enrichment is a singular cause of action like contract,${ }^{61}$ there is increasing support for the view that it is a category of claims (like the category of claims collectively known as 'torts') which share certain common features. From this perspective, the 'four questions may serve to focus attention on the nature, availability and measure of restitutionary relief, and so assist in structuring understanding as to avoid the development of the law of unjust enrichment degenerating into an exercise in idiosyncratic discretion' ${ }^{62}$ Utilising those questions, the contributions to this part, as well as Parts V and VI, investigate the principles of unjust enrichment and restitution law across common law jurisdictions in order to contribute to that structured understanding.

Civilian approaches to these questions are also helpful in understanding the nature and operation of unjust enrichment and restitution law. As in the common law, identifying an actionable enrichment that has come at the expense of the plaintiff is necessary, but not sufficient. Something more is required. Here, as we intimated when discussing Gordley's contribution above, civilian systems are often distinguished from their common law counterparts through their approach to the third question of what more is required to render a defendant's retention of enrichment 'unjust'. While common law systems typically require proof of some positive 'unjust factor' such as mistake or duress, jurisdictions in the civilian tradition intervene where there is no legally recognised basis (also referred to as 'juristic basis' or 'juristic reason') for the defendant's enrichment. However, as the chapters by Häcker in this part, and Krebs in Part $\mathrm{V}$, demonstrate, there are notable overlaps both in the problems identified by both systems and

60 Birks, Introduction (n 2) 1.

61 Compare e.g. Banque Financière de la Cité v Parc (Battersea) Ltd [1999] AC 221, 227 (Lord Steyn) and Crown Prosecution Service v Eastenders Group [2014] UKSC 26, [2015] AC 1 [100] (Lord Toulson, with whom Lady Hale and Lords Kerr, Wilson and Hughes agreed).

${ }^{62}$ Mann (n 42) [213] (Nettle, Gordon and Edelman JJ), their Honours also noting that recent developments suggest that the 'law of restitution in the United Kingdom and the law of restitution in Australia are no longer quite as far apart as was previously imagined', citing Investment Trust (n 32) [40]-[42] (Lord Reed JSC, Lord Neuberger PSC, Lord Mance, Lord Carnwath and Lord Hodge JJSC agreeing); Swynson (n 32) [22] (Lord Sumption JSC, Lord Neuberger, Lord Clarke and Lord Hodge JJSC agreeing), [110][112] (Lord Neuberger PSC). See also Skandinaviska Enskilda Banken AB (Publ) v Conway [2019] UKPC 36, [2019] 3 WLR 493 [79]-[80] (Lord Reed, Lord Wilson, Lord Lloyd-Jones, Lord Briggs and Sir Donnell Deeny). 
the doctrinal solutions adopted by them from time to time. The difference is one more of technique than substance. ${ }^{63}$ This conclusion opens the door for rich insights to the benefit of each, both on the current state of the law and potential pathways for judicial and legislative reform.

The diversity of perspectives brought to bear by contributors to this part on the key questions underpinning claims in unjust enrichment reveal some common themes, which go to the heart of this field of law. First is the law's search for appropriate and adapted doctrinal mechanisms by which the strict restitutionary liability of the defendant recipient may be tempered: this most clearly underpins the debates over what counts as an actionable enrichment and defences, ${ }^{64}$ but also permeates the development of the 'unjust factors' (for example, whether causative mistakes of any kind are sufficient to yield restitution, the concept of 'defendant-sided' unjust factors) and the necessary link between defendant and plaintiff expressed through the 'at the expense of' element. ${ }^{65}$ It also informs the ongoing debates over the respective roles and advantages of the common law 'unjust factors' as compared to the civilian 'juristic reasons' approach. ${ }^{66} \mathrm{~A}$ second theme, linked to the first, is the form of reasoning employed by courts to determine restitutionary liability. While a rule-based approach promotes stability and predictability, courts increasingly have declined to be so fettered, continuing to apply open-textured concepts such as 'risk', ${ }^{67}$ 'reasonableness', ${ }^{68}$ ' 'good faith', ${ }^{69}$ as well as what is 'equitable' or 'unconscionable ${ }^{70}$ to determine liability. ${ }^{71}$ The third is the normative unity and thus scope of the unjust enrichment category. This theme is manifested in a range of debates, including over the availability of claims against remote recipients,,$^{72}$ the integration of equitable principles ${ }^{73}$ and whether policy-based reasons for restitution share sufficiently common characteristics with the other 'unjust factors' to come within the same category of claim..$^{74}$ The final and related theme is the interaction between unjust enrichment and its neighbouring private law doctrines. As a body of law still trying to define itself, and hence find its rightful place in private law, its relationship to core legal concepts of property, contract and wrongdoing is a matter of near constant dispute. ${ }^{75}$ In these respects, this part reinforces the ongoing relevance of the taxonomic and philosophical enquiries (the subject of earlier chapters) to working doctrine.

\footnotetext{
63 Häcker (Chapter 15) p. 290.

64 McInnes (Chapter 13) and also Part V Defences.

65 Chen-Wishart and Gregson (Chapter 16), Watterson (Chapter 14).

66 Häcker (Chapter 15).

${ }^{67}$ In mistake, see Chen-Wishart and Gregson (Chapter 16) p. 320 and failure of basis, see, e.g., Burrows (Chapter 17) p. 347.

${ }_{68}$ In enrichment and change of position defence, discussed in McInnes (Chapter 13) p. 257 and Grantham (Chapter 21) p. 428.

${ }_{69}$ In areas as diverse as duress, see Chen-Wishart and Gregson (Chapter 16) p. 327, and change of position, see Grantham (Chapter 21) p. 428.

70 See, e.g., Hills Industries (n 46) [1] (French CJ), [65]-[67] (Hayne, Crennan, Kiefel, Bell and Keane JJ), [155] (Gageler J).

${ }_{71}$ The Australian aversion to being overly constrained by the four-fold enquiry is discussed in E Bant, 'Reflections on the Restitution Revolution: Australia' in S Worthington, A Robertson and G Virgo (eds), Revolution and Evolution in Private Law (Oxford, Hart Publishing, 2018) 193.

${ }_{72}$ Watterson (Chapter 14) and Bryan (Chapter 18).

73 Chen-Whishart and Gregson (Chapter 16).

74 Mitchell (Chapter 19).

75 McInnes (Chapter 13), Burrows (Chapter 17), Bryan (Chapter 18) and Mitchell (Chapter 19).
} 
In Chapter 13, Mitchell McInnes opens the doctrinal analysis of unjust enrichment within the collection with an examination of the core concept of 'enrichment'. As he explains, this first element of unjust enrichment claims is complex for a number of reasons, but most importantly because of its critical role in ensuring that the defendant is not subject to unjust demands for restitution. Alongside the defence of change of position, ${ }^{76}$ the law protects against this risk by demanding that '[o]nly those benefits that are consistent with the recipient's freedom of choice can lead to liability' ${ }^{77}$ McInnes traces the different forms and methods of categorising enrichments (including positive and negative, factual and legal benefits, exchange and use value, as well as possession and title) before turning to consider one of the law's main protective mechanisms for innocent recipients, the concept of 'subjective devaluation'. While this aims to safeguard the defendant's freedom of choice in respect of how to allocate his or her personal resources, McInnes argues that its label tends to suggest, misleadingly, that the defendant's personal valuation of a received benefit is relevant, so that she could plead it to make herself liable for less than the benefit's market value, as well as some legitimate role for 'over-valuation' (the doubtful idea that she can be made liable for more than its market value if the plaintiff can prove that she personally valued it at a higher rate). McInnes goes on to identify and evaluate the main 'tests' of enrichment by reference to this protective aim of the enrichment enquiry. He categorises the various tests into two broad camps: cases where the enrichment constitutes an 'incontrovertible benefit' to the defendant, such that the defendant cannot but acknowledge substantive enrichment, and those where the benefit results from 'an exercise of choice' by the defendant. His rigorous analysis of their manifestations and applications draws on leading cases from Australia, Canada, England and New Zealand to reveal the complex legal and policy issues addressed by the tests. The chapter concludes by considering the difficult and important task of 'quantification' of enrichment. As McInnes observes, this serves multiple functions: to identify the defendant as the recipient of a reversible transfer; to protect the identified defendant's autonomy and to determine the quantum of recovery. Here, determining the time and objective measure of the defendant's enrichment remain key challenges.

\section{B At the Expense of}

The key requirement that the unjust enrichment of the defendant be 'at the expense of' the plaintiff is disarmingly straightforward. As Stephen Watterson carefully and insightfully demonstrates in Chapter 14, it conceals a number of conceptual and normative inquiries central to liability in unjust enrichment. Most obviously, 'at the expense of' performs a standing-related function, denoting the connection sufficient in law to enable a particular plaintiff to seek a restitutionary remedy from a particular defendant. Obscured within this inquiry is the complexity provided by the fact that courts have recognised restitutionary claims in numerous multi-party fact-patterns, where the plaintiff did not himself pay, transfer title, or render services to the defendant, and where a superficial analysis might suggest that the defendant was more immediately enriched by a third party. Some examples of such cases are:

76 See the discussion in Grantham (Chapter 21).

77 McInnes (Chapter 13) p. 238. 
(1) where the plaintiff paid the third party as the defendant's agent or the third party, as the plaintiff's agent, paid the defendant; (2) where the plaintiff paid the defendant in performance of the plaintiff's contract with a third party which obliged the third party to confer a benefit on the defendant; (3) where the plaintiff paid the third party in discharge of the defendant's liability to that third party; and (4) where the defendant received from the third party money, or an asset, which was obtained by the third party from the plaintiff, or which represented the traceable proceeds of such money or asset. ${ }^{78}$ Watterson skilfully traverses this territory, providing a useful roadmap of the academic and judicial debates surrounding these questions.

In addition, as Watterson explains, 'at the expense of' also raises further questions that influence the measure of any remedy available. These include, in particular, whether any monetary restitutionary remedy for a defendant's unjust(ified) benefit should be capped by the plaintiff's 'corresponding' loss or deprivation, ${ }^{79}$ and whether any remedy can extend to remoter, consequential ${ }^{80}$ or incidental benefits. ${ }^{81}$ The answers given to these questions - and in particular, the sense (if any) in which the plaintiff must suffer any initial or ultimate 'loss' - will vitally affect arguments concerning the existence and extent of a passing on defence. In that sense there is a link between the debates conducted here and those that surface under the 'Defences' heading below. ${ }^{82}$

\section{Unjust Factors and the Absence of a Basis for an Enrichment}

In Chapter 15, Birke Häcker provides a detailed investigation into the different analytical approaches taken to unjust enrichment law by common law (the 'unjust factors' approach) and civilian jurisdictions (the 'absence of basis' or 'unjustified' enrichment model), drawing attention to their respective advantages and disadvantages. She observes in the process what she describes as a growing pressure on common law systems to switch to the civilian approach. Here she notes what one might consider to be good evidence of this trend in the form of Peter

78 See also Bryan (Chapter 18), Liau and Leow (Chapter 24).

79 See, e.g., the work of Mitchell McInnes, who argues, consistently with the Canadian position which holds that the plaintiff must have suffered a 'corresponding deprivation' to the defendant's enrichment, that any monetary restitutionary remedy should be capped at the plaintiff's loss, if this is less than the defendant's gain: M McInnes, The Canadian Law of Unjust Enrichment and Restitution (Markham, LexisNexis, 2014) ch 3, esp 183-99; M McInnes, "AAt the Plaintiff's Expense": Quantifying Restitutionary Relief' (1998) 57 CLJ 472; M McInnes, 'The Measure of Restitution' (2002) 52 University of Toronto Law Journal 163.

${ }^{80}$ This question arose in Prudential Assurance Co Ltd $v$ HMRC [2018] UKSC 39, [2018] 3 WLR 652 ('Prudential'). The UK Supreme Court rejected a claim for the use value of money itself recoverable as mistakenly paid tax. The Court held at [70]-[72] and [73]-[74] that this benefit is not obtained 'at the plaintiff's expense' in the required sense: there is no additional qualifying 'transfer of value' between plaintiff and defendant, beyond the initial 'direct' transfer of value involved in the mistaken payment.

${ }_{81}$ Familiar examples include: $\mathrm{C}$ occupier, who heats his downstairs flat, and saves the defendant, his upstairs neighbour, the expense of heating; $\mathrm{C}$ quarry-owner, who drains his quarry of water, and saves a neighbouring quarry-owner the expense of draining his own; and $\mathrm{C}$ landowner, who cuts down trees on his land, improving the view of the defendant neighbouring landowner and his property's value. In Investment Trust (n 32) [52]-[58] (Lord Mance JSC) the UK Supreme Court held there is generally no liability for 'incidental benefits', which arise as a collateral result of a plaintiff's actions directed to a different objective, as such benefits are not obtained 'at the plaintiff's expense' in the required sense.

${ }^{82}$ For the most extensive exploration of this linkage, see M Rush, The Defence of Passing On (Oxford, Hart Publishing, 2006) pt II. 
Birks' well-known abandonment of the common law approach in the face of a particular set of cases ('the swaps litigation') which he did not believe could be solved with its standard analytical tools. Whether this was actually the case (and the intellectual change of heart was needed) remains a matter of contention. Both English and American courts have hitherto remained faithful to the traditional (unjust factors) approach, although they have left the possibility of change hanging in the wind. Consistently with the views we have expressed above, Häcker points out that the difference between the approaches is largely one of technique, not substance, and that they tend to yield very similar results, albeit via different intellectual routes. The civilian technique is more abstract and can therefore appear simpler, but the semblance of simplicity probably just hides its inherent complexities, while the common law wears them on its face. She also considers a number of 'mixed' analytical models that combine elements of both approaches, by asking both whether there is a good reason to require restitution of the defendant's benefit and any good reason for the defendant to retain it. As we suggested above ${ }^{83}$ it is likely that both types of question will need to be asked somewhere in all systems and the main issue is with which of them one starts. The starting point is in great part a product of jurisdictional history, but it may also, it has been suggested, reveal one's more basic moral beliefs - whether one thinks that the gains the defendant makes have, prima facie, to be explained before they can be kept, or whether they must be shown to be questionable before the plaintiff can claim them. ${ }^{84}$

In Chapter 16, Mindy Chen-Wishart and Rory Gregson provide the first of a series of detailed examinations of the range of 'unjust factors' that operate to support claims for restitution within common law systems. As the authors observe, at a high level of generality, there is consensus that impaired intention plays an important role in justifying some cases of restitution for unjust enrichment. The leading view is illustrated by Lord Sumption SCJ in Swynson Ltd v Lowick Rose LLP: $:^{85}$ an unjust enrichment claim requires the plaintiff to prove one of a list of unjust factors, and impaired intention unites the largest group of unjust factors. The same view is put forward by Burrows and Goff \& Jones, ${ }^{86}$ and was originally proposed by Birks. ${ }^{87}$ According to this explanation, an unjust factor is a reason why the defendant's enrichment is unjust, while an impaired intention unjust factor locates that reason in the impairment of the plaintiff's intention to enrich the defendant. Thus, Chen-Wishart and Gregson consider the unjust factors of mistake, incapacity, duress, undue influence, non-commercial guarantees, unconscionable bargains, and legal compulsion, all of which are traditionally presented as explicable by impaired intention. ${ }^{88}$ It may be added that, in all cases, the vitiated intention must have caused the plaintiff to enter into a transaction that enriched the defendant. ${ }^{89}$

83 When discussing Gordley's thesis, above p. 4.

${ }^{84}$ K Barker, 'Responsibility for Gain: Unjust Factors or Absence of Basis? Starting Points in Unjust Enrichment Law' in C Rickett and R Grantham (eds), Structure and Justification in Private Law (Oxford, Hart Publishing, 2008) 47.

${ }^{85}$ Swynson (n 32) [22] (Lord Sumption SCJ) (citations omitted).

86 Burrows, Restitution (n 22) 86; Burrows, Restatement (n 22) 5-6, 30; Goff \& Jones (n 22) [1-25]. 87 Birks, Introduction (n 2).

88 ibid; Burrows, Restitution (n 22) 86; Burrows, Restatement (n 22) 5-6, 30; Goff \& Jones (n 22) [1-25]; Virgo, The Principles of the Law of Restitution (n 21) 121.

89 The applicable tests of causation are highly contested both as a matter of principle and authority. The chief options are the 'but for' and contributory 'a factor' tests: compare Burrows, Restitution (n 21) 91-5; Edelman and Bant (n 26) 190-4 (mistake), 219-23 (duress), 235-42 (undue influence); M 
However, the authors contend that within the impaired intention unjust factors themselves, the law takes into account more than just the plaintiff's impaired intention. With the unjust factors of mistake, incapacity, and duress, the plaintiff's impaired intention gets the law's foot in the door. But then many other considerations identified by the authors determine whether restitution should in fact be given. By contrast, with the unjust factors of undue influence, non-commercial guarantees, unconscionable bargains, and legal compulsion, impaired intention plays little or no role at all. In undue influence and non-commercial guarantee cases, the authors argue that restitution is awarded to protect the social form of trusting relationships. In unconscionable bargain cases, restitution is justified by the protection of vulnerable parties from oppressive transactions. In legal compulsion cases, the law looks to distribute properly the burden of a common liability. Indeed, the authors maintain that these unjust factors justify restitution even where the plaintiff's intention to enrich the defendant is unimpaired.

In arguing for a more sophisticated account of these unjust factors, which acknowledges that 'other values are in play', Chen-Wishart and Gregson entreat us to develop a taxonomy which is realistic and respectful of the norms and realities of the position and relationships of the parties. Additionally, as they acknowledge, there may be other consequences. For example, some may argue that, since unjust enrichment law awards restitution where the plaintiff's intention to enrich the defendant is impaired, a fortiori it should award restitution where the plaintiff's intention to enrich the defendant is absent. ${ }^{90}$ However, if we accept that impaired intention is neither a necessary, nor a sufficient reason for restitution, then the premise of this argument disappears. Further, in advancing the underlying disunity of the impaired intentions category (or core), Chen-Wishart and Gregson again raise potential doubts over the extent to which unjust enrichment is a unified subject. ${ }^{91}$

In Chapter 17, 'Conditional Intention as an Unjust Factor', Andrew Burrows focuses on what may be considered, after mistake, as the 'unjust factor' of greatest theoretical and practical importance in the law. Notwithstanding its confusing nomenclature, 'failure of consideration' concerns cases where a plaintiff has conferred a benefit on the defendant 'conditionally on a performance or event that has not materialised'. It may therefore be better understood as 'failure of condition', to avoid any contractual mis-association. Unlike mistake, this unjust factor is concerned with conditional rather than vitiated intention, and the relevant condition is assessed objectively on a bilateral basis, ${ }^{92}$ by looking at the manifested understanding of both

McInnes, The Canadian Law of Unjust Enrichment and Restitution (n 79) 385-90 (mistake) 445-6 (duress) 509-10 (undue influence). In some jurisdictions, statutory schemes have made the relevant test of decision causation acutely significant as a matter of practice: see E Bant and JM Paterson, 'Statutory Causation in Cases of Misleading Conduct: Lessons from and for the Common Law' (2017) 24 Torts Law Journal 1.

90 Bryan (Chapter 18). See further Birks, Introduction (n 2) 141; Burrows, Restitution (n 21) 403; Burrows, Restatement (n 21) 93; Edelman and Bant (n 26) 279-80, 300. For criticism, see W Swadling, 'Ignorance and Unjust Enrichment: The Problem of Title' (2008) 28 Oxford Journal of Legal Studies 627.

91 Swynson (n 32) [30] (Lord Sumption SCJ); Prudential (n 80) [68] (Lord Mance, Lord Reed, and Lord Hodge SCJJ); Webb (n 56) ch 3; Stevens, 'The Unjust Enrichment Disaster' (2018) 134 LQR 574; L Smith, 'Restitution: A New Start?' in P Devonshire and R Havelock (eds), The Impact of Equity and Restitution in Commerce (Oxford, Hart Publishing, 2019) 110-11.

${ }_{92}$ As explained in Roxborough v Rothmans of Pall Mall Australia Ltd (n 40) [104] (Gummow J): " "failure of consideration" identifies the failure to sustain itself of the state of affairs contemplated as a basis for the payments the appellants seek to recover'. See also at [16] (Gleeson CJ, Gaudron and Hayne 
parties. Burrows explains that, once understood as involving the failure of the condition on which a benefit is transferred, the law's requirement that the failure is 'total' is more readily understood and justified. Either a condition is met or it fails: all therefore turns on the characterisation of the condition itself, an analysis (it may be added) supported by the recent High Court of Australia's decision in Mann v Paterson Constructions. ${ }^{93}$ Having earlier separated the unjust factor from concepts of contractual consideration, Burrows goes on to consider its operation in a variety of contractual and pre-contractual contexts. He demonstrates powerfully the critical importance of close characterisation of the objective condition on which the benefit was transferred, as well as separating out the unjust factor enquiry from the measure of enrichment. In all cases, the contractual context may well shape the defendant's liability, but it will do so because the law of unjust enrichment moderates restitutionary liability in a way that captures the nuance of that broader legal context. This is of particular importance when considering the vexed question of 'contract ceilings' in the context of contracts terminated for breach, but also supports recognition of liability for failure of condition in cases of services, and in cases where the failed condition is an event other than promised performance. Burrows concludes by assessing whether an unjust factor of 'free acceptance' can be supported as a matter of precedent, principle or policy. In concluding that it does not, Burrows reinforces the highly influential position taken by him in his seminal article on the topic. ${ }^{94}$

In 'No Intention to Benefit' (Chapter 18), Michael Bryan shifts the focus of the collection from cases of vitiated or conditional intention, to ones where a plaintiff's intention to enrich the defendant is wholly absent. He argues forcefully that, seen against the core vitiated and conditional intention unjust factors, the normative justifications for recognition of this class of unjust factor are compelling. Bryan divides the relevant cases into (1) categories of 'ignorance' and 'powerlessness', where 'the plaintiff's intentions play no part in the event that causes the defendant's enrichment'; and (2) cases of 'anti-beneficial transfer', where 'the plaintiff intended to pass legal title to the enrichment but had no intention to confer beneficial title by way of gift, contract or express trust'. Bryan traces the manifestations of, and controversies surrounding, these categories across the spectrum of common law and equity. As he notes, a key problem for acceptance of the category has been confusion over the doctrinal importance of labels (such as 'ignorance') as opposed to the substance of the reasoning for which they stand as short-hand. To this, one might add the wholly opaque nature of the forms of action ${ }^{95}$ and, in the modern age, the ever-present possibility of 'alternative analysis' or concurrent claims. ${ }^{96}$ These combine to render almost every aspect of this unjust factor controversial. However, Bryan demonstrates that, of its nature, this class of unjust factor also turns an important spotlight on key elements of the broader category of unjust enrichment, in particular challenging rights- and transfer-based conceptions of both 'enrichment' and the 'at the expense of' enquiry, as well as the continuing segregation of related equitable doctrines. ${ }^{97}$

JJ): 'Failure of consideration is not limited to non-performance of a contractual obligation, although it may include that ... the concept embraces payment for a purpose which has failed as, for example, where a condition has not been fulfilled, or a contemplated state of affairs has disappeared.'

3 Mann (n 42).

94 A Burrows, 'Free Acceptance and the Law of Restitution' (1988) 104 LQR 576.

95 As to which, see Ibbetson (Chapter 2).

96 Fistar v Riverwood Legion and Community Club Ltd [2016] NSWCA 81, (2016) 91 NSWLR 732

[48] (Leeming JA).

${ }_{97}$ Compare Ho (Chapter 7), McInnes (Chapter 13) and Watterson (Chapter 14). 
The chapter makes a powerful case that, understood properly, a class of unjust factor concerned with 'no intention to benefit' may operate to promote increased rationality both in the development of common law and equitable principles of unjust enrichment and restitution and their neighbouring legal contexts.

In Chapter 19, Charles Mitchell concludes Part IV by considering 'other reasons' for restitution which turn on neither the defendant's wrongdoing, nor on the conditionality, defectiveness or absence of the plaintiff's intention to benefit the recipient. Mitchell points out that, while judicial authority provides clear examples in which restitution has been awarded for these 'other reasons', there exists fundamental disagreement as to what normative and doctrinal foundations support the 'other reasons' category.

In his original taxonomy of unjust factors or reasons for restitution, Peter Birks identified cases of so called 'policy motivated restitution' as being those in which courts have identified particular interests as supporting restitutionary relief, after undertaking a balancing exercise which 'balances goods and bads' ${ }^{98}$ Mitchell considers that, even on this Birksian understanding, the 'policy motivated' category could also capture unjust factors which turn, for example, on defective or absent intention, since these prioritise the interest which plaintiffs have in making free and well informed choices about the disposal of their resources. Thus Mitchell observes that the Birksian label does not distinguish cases of absent, qualified and vitiated intention from other cases in which the defendant has committed no wrong. Mitchell also critiques the views of Edelman and Bant, who argue that cases of restitution for unjust enrichment in response to a vitiated intention form a sufficiently normatively unified category, which effects 'interpersonal justice between the parties' ${ }^{99}$ Edelman and Bant argue that cases of 'policy' motivated claims or 'other' claims validate an interest or institution, or achieve a goal external to the parties and, for this reason fall outside the unified core of restitution for unjust enrichment (albeit that they may be examples of restitution triggered by other events). Grantham and Rickett similarly point to the lack of conceptual unity in the 'other' category. ${ }^{100}$

In response, Mitchell questions the degree of normative unity that a body of legal rules must possess before it is regarded as a meaningful category of obligations law, pointing out that accepted categories such as contract and tort may well fail to meet the stringent normative unity required by Edelman and Bant and also Grantham and Rickett. Rather, Mitchell takes the 'pluralist' view which understands restitution of unjust enrichment to be awarded for a variety of different reasons, but which all also present similar issues about the identification and valuation of enrichment, the identification of circumstances in which benefits are relevantly gained at the plaintiff's expense, and the identification of defences (meaning reasons why a defendant should be able to keep a benefit although the plaintiff has a prima facie cause of action). Mitchell then discusses six situations in which the reason for restitution turns neither on the defendant's wrongdoing against the plaintiff, nor on the plaintiff's intention to benefit the defendant: where money has been paid as tax that was not due; where money has been paid in accordance with a judgment that was later reversed; where money has been paid pursuant to a secondary liability; where benefits have been conferred in an emergency; where benefits have been transferred as part of a scheme to accomplish an illegal purpose; and where benefits

98 Birks, Introduction (n 2) 294.

99 Edelman and Bant (n 26) 125, 127-30, 302.

100 RB Grantham and CEF Rickett, Enrichment and Restitution in New Zealand (Oxford, Hart Publishing, 2000) ch 4, esp 45. 
have been conferred by a person who lacked legal capacity. We observe that the sheer range of claims to which restitution may respond highlights the importance of determining the extent to which, notwithstanding their shared features, their differences demand distinct treatment. One area where this is of particular importance is defences, to which we now turn.

\section{DEFENCES}

The availability of defences is a critical component in the unjust enrichment enquiry and is the focus of Part V of the collection. Defences ensure that the strict liability of unjust enrichment operates to reverse the defendant's enrichment rather than to impose loss on the defendant, and serve to balance the liability equation by recognising the position of the defendant. Thus, recognition of a change of position defence has been accredited with enabling the relative liberalisation of unjust factors such as mistake. ${ }^{101}$ However, as Graham Virgo notes in his 'Taxonomy of the Defences in Restitution' (Chapter 20), defences are relatively under-explored in the literature and there has been no concerted effort to provide a comprehensive theory that explains them. In that context, Virgo's chapter seeks to provide a new foundation for better understanding the conditions and limits upon restitution for unjust enrichment, as well as for restitution that rests on the assertion of a pre-existing proprietary interest. Building on the work of James Goudkamp, ${ }^{102}$ he commences this task by distinguishing denials (which refute that an element of the primary claim has been established) from defences (which are relevant once the cause of action has been established to indicate a reason why liability should not be imposed) and bars, which are raised by a defendant, but must be countered by the plaintiff as a condition of recovery. The most important of these from the perspective of a claim in unjust enrichment is the 'legal basis' bar, where the defendant claims to have a legal justification or entitlement to the enrichment received from the plaintiff.

Building on these distinctions, Virgo proposes two categories of defences properly-so-called. In one category are those defences founded on considerations of interpersonal justice as between plaintiff and defendant. The other category encompasses those defences which have regard to matters external to the parties, where the balance of justice is determined by public policy considerations. Virgo evaluates other dichotomies that may assist to classify restitutionary defences: enrichment- and injustice-related defences; public and private defences; rule-based and discretionary defences; and personal and proprietary defences. He then uses the insights garnered from this analysis to rationalise the core defences of change of position, estoppel, the 'weak' form of ministerial receipt (sometimes called 'payment over') and illegality, as well as to consider the roles for potential defences of passing on and subjective devaluation.

In Chapter 21, 'Change of Position-based Defences', Ross Grantham turns from Virgo's higher-level taxonomical analysis to examine the specific defences to unjust enrichment of change of position, estoppel and 'good consideration'. Grantham observes that while each of the defences may address changes in the defendant's position, and rest on a shared concern that the normative justification of the unjust enrichment claim does not extend beyond restoration

101 See, e.g., Barclays Bank Ltd v WJ Simms Son and Cooke (Southern) Ltd [1980] QB 677, 695 (Goff J); Lipkin Gorman (n 4) 581 (Lord Goff).

102 J Goudkamp, Tort Law Defences (Oxford, Hart Publishing, 2017). 
(for example to compensation or punishment), this does not mean that the defences should be merged. He sees change of position and estoppel as occupying overlapping positions, but with sufficient points of distinction and areas of uncertainty in their application to justify their continued independence. By contrast, the work to be done by 'good consideration' seems largely covered by change of position, policy-based concerns and, in particular, by arguments that the defendant was entitled to receive and retain the benefit. Here, Grantham agrees with Virgo that 'good consideration' as a means of showing that the defendant was entitled to a benefit is better characterised as a bar than a defence.

Grantham's chief focus in the chapter is on the change of position defence, which serves to put the other defences in context. Here, he argues that the High Court of Australia was right to conclude that the rationale of the defence goes beyond 'disenrichment' 103 to capture non-pecuniary changes that would leave the defendant 'worse off' by being required to make restitution. However, he does not accept the assessment by a majority of the justices that this entails consideration of the 'reversibility' of the defendant's change of position, ${ }^{104}$ preferring in the interests of certainty and transparency Gageler J's view that the defence should operate completely unless the detriment is pecuniary and therefore quantifiable. ${ }^{105}$ Grantham subjects the elements of the defence (detriment, causation and good faith) to detailed analysis, to show that they are largely consistent with its underlying rationale. He concludes his analysis by considering the extent to which the defence operates outside the paradigm case of mistake, as well as to proprietary claims and wrongs. In each case, his analysis demonstrates the importance of close consideration of the nature and elements of each claim and assessment of the application of the defence in light of its rationale and elements. On this approach, the defence will not automatically apply to all claims in unjust enrichment, nor will it automatically be denied in cases of wrongs.

Thomas Krebs' consideration in Chapter 22 of the German defence of 'disenrichment' not only provides a window into this core restriction on the unjust enrichment principle, but a comparative perspective on the defences forming the subject of the preceding two chapters. Krebs explains key characteristics of disenrichment as codified in $\S 818$ III, IV and $\S \S 819$ and $820 \mathrm{BGB}$, its relationship to other provisions governing liability and the major controversies surrounding the defence. The heart of the defence is simple: it operates to exclude restitution to the extent that a good faith recipient is no longer enriched. However, thus drawn, the defence has been accepted to be unacceptably generous to the unjust enrichment debtor, the only express limit being that the defence will not apply to disenrichments that are suffered after service of proceedings. Thus, unlike its common law counterpart, ${ }^{106}$ it is clear that there is no requirement for reliance on the part of the defendant: indeed, the loss of the received object provides a defence even in insolvency. Efforts to limit the ambit of the defence through such interpretive routes as the Saldotheorie have generated their own problems, producing at times quite different results between otherwise very similar cases and hence generating, in turn, numerous exceptions to the rule. As Krebs notes, a root of the problems with 'disenrichment' lies in the Code's failure squarely to address whether restitution is concerned with reversing transfers of value, or reversing failed transfers of things or objects. This uncertainty is also

103 cf McInnes (Chapter 13).

104 Hills Industries (n 46) [23]-[31] (French CJ), [95] (Hayne, Crennan, Kiefel, Bell and Keane JJ).

105 ibid [158].

106 Grantham (Chapter 21) p. 426. 
reflected in debates over the relationship between the disenrichment rules and rules governing those in good faith possession of another's property. Similar debates are currently raging in common law jurisdictions. ${ }^{107}$ Krebs concludes that the way forward may lie in a closer focus on the reasons for the enrichment claim and thus a better understanding of when and whether the defendant is entitled to rely on the security of receipt.

\section{RESTITUTIONARY REMEDIES}

The final part of the collection explores the nature of restitutionary remedies. ${ }^{108}$ In Chapter 23 Katy Barnett distinguishes between the remedies of restitution, compensation and disgorgement. As she explains, these are often confused and conflated by both courts and commentators. This has serious ramifications for coherent legal explication, case resolution and development. Barnett observes that the factual consequences of a triggering event such as a mistaken payment, may vary. In some circumstances, a plaintiff may suffer a loss as a result of the event; in others, a defendant may gain as a result of a triggering event. Sometimes, both losses and gains will be present on the facts and will correlate: here an order that the plaintiff defendant's gain must be restored to the plaintiff will address both elements. However, in other cases the plaintiff does not make a loss, or suffers a minimal loss, but the defendant gains as a result of his wrongdoing. Depending on the correct analysis, the amount of gain or loss may diverge, and it will obviously be in the interests of the plaintiff to seek the higher amount. In such cases, correct characterisation of the nature and availability of the remedy will be critical. Other ramifications also flow: for example, the rules limiting recovery (such as remoteness rules and defendant allowances) and defences which apply to awards of gains, losses, and restitution are different depending on the relevant remedy. As Barnett demonstrates, considerable confusion can bedevil the law where the distinctions between compensation, restitution and disgorgement are not kept firmly in mind. This is most apparent in the area of 'reasonable fee' awards, also the subject of analysis by Rotherham in Chapter 5. In relation to 'reasonable fees' awards, Barnett argues that the lengths to which courts have gone to provide compensatory analyses of these awards threatens to destabilise the law of compensation more generally. However, she does not therefore embrace a restitutionary analysis. Rather, Barnett concludes that a disgorgement analysis best fits the patterns of reasoning and justifications for user damages awards, with ramifications for bars, defences, remoteness and mitigation considerations.

Timothy Liau and Rachel Leow conclude the collection in Chapter 24 with their examination of 'Proprietary Restitution'. As they note, the availability of specific relief may be highly desirable, as where the plaintiff wishes to recover a valued heirloom. And proprietary relief may have ancillary advantages, such as supporting tracing claims against remote recipients and

107 See McInnes (Chapter 13) and Liau and Leow (Chapter 24) on the rights-value debate and Grantham (Chapter 21) on bailment. For specific discussion of the Saldotheorie and issues for the common law defence of change of position, see E Bant, 'Rights and Value in Rescission' in D Nolan and A Robertson (eds), Rights and Private Law (Oxford, Hart Publishing, 2012) 609.

108 The availability and measure of restitutionary remedies are also the subject of analysis in Rotherham (Chapter 5) and McInnes (Chapter 13). 
advantages in insolvency. ${ }^{109}$ However, as the authors explain, the law has yet to settle on when and why these advantages should be bestowed on the unjust enrichment plaintiff. Judicial decisions (and consequently commentators) variously favour that they should never, sometimes, or always follow. Liau and Leow focus on two possible styles of approach to understanding the availability of proprietary restitutionary relief: those which identify additional reasons that justify the award of proprietary restitution as an exceptional remedy, and those which find the justification for proprietary restitution innate within the existing structure of the core claim. An example of the former type of approach is the theory that proprietary restitution is only available where the benefit that was received was relevantly unique, so that personal restitution is not sufficient to enable the defendant to be restored to her former position. ${ }^{110}$ An example of the latter is Chambers' influential thesis that divides enrichment into value and rights. ${ }^{11}$ As the authors note, both have their strengths and weaknesses and neither yet commands the field. The position is further complicated by the variety of forms of order that may give effect to proprietary restitution. Here Liau and Leow examine the forms of remedy supported in the cases, dividing them into trusts, powers to re-vest rights and security interests. They show that these have variously been awarded for a wide variety of unjust factors, a position that clearly may be subject to justified criticism of incoherence. For example, why do equivalent circumstances of undue influence support the award of either a trust, rescission and lien, respectively? ${ }^{112}$ Liau and Leow do not attempt to provide a way through the thicket; however their map makes clear the nature of the challenging terrain ahead. Their analysis also reinforces the close connection between the nature of the remedy and that of the claim to which it responds.

\section{CONCLUSIONS}

Once the idea that the law of unjust enrichment and restitution is a distinct department of private law is accepted, it becomes essential to engage with the normative and doctrinal settings and architecture of the field, as well as with the relationships between it and other private law categories. As the contributions to this book show, the field raises issues which are broad, significant and, at times, extremely difficult. There is no doubt that debate will continue as the law develops further and gains in maturity. However, what cannot be denied from the body of work contained in this book is the great evolution in theory and practice that has taken place within common law systems since the early writings of Goff and Jones, and Birks, ${ }^{113}$ as well

109 Whether they should have these advantages is strongly disputed: see, e.g., E Bant and M Bryan, 'Specific Restitution without Trusts' (2012) 6 Journal of Equity 181; W Swadling, 'Constructive Trusts and Breach of Fiduciary Duty' (2012) 18 Trusts and Trustees 985; R Goode, 'Property Liability for Secret Profits - A Reply' (2011) 127 LQR 493, 494; D Paciocco, 'The Remedial Constructive Trust: A Principled Basis for Priorities over Creditors' (1989) 68 Canadian Bar Review 315.

${ }_{110} \mathrm{~J}$ Edelman, 'Restitution of (Property) Rights' in E Bant and M Bryan (eds), Principles of Proprietary Remedies (Pyrmont, Lawbook Co, 2013) 37; Bant and Bryan (n 109).

${ }_{111}$ R Chambers, 'Two Kinds of Enrichment' in R Chambers, C Mitchell and J Penner (eds), Philosophical Foundations of the Law of Unjust Enrichment (Oxford University Press, Oxford, 2009) 242.

112 E Bant, 'Trusts Powers and Liens: An Exercise in Ground-Clearing' (2009) 3 Journal of Equity 286.

113 See text to n 11; Goff and Jones (n 11); Birks, Introduction (n 2). 
as the significant guidance that may be gained from paying close attention to the experience of civilian traditions. The importance of obtaining a solid understanding of the key features, operation and limits of the field cannot, in our view, be overstated and is unlikely to be doubted by anyone operating in modern commercial practice.

It has been the aim of this book to provide that foundation of knowledge. It is the hope of its editors that it will inspire future generations of scholars, practitioners, reformers and judges to contribute to the law's continued, principled development. Thanks to the remarkable contributions so generously provided by leading commentators from across the globe, these high aspirations are tantalisingly within reach. 